\title{
EL MARTIRIO DE SAN ESTEBAN DE QUINTANA Y LOS ORÍGENES DE LA CIUDAD SANTA IDEALIZADA
}

\author{
Jesús Rodríguez Bravo*
}

\section{RESUMEN}

En la última etapa de su vida, Cristóbal Hernández de Quintana pintó el Martirio de san Esteban. El cuadro fue comprado en 1781 para que se colocara en la sacristía principal de la nueva iglesia de la Concepción de La Orotava, aún sin concluirse. El mensaje de esta pintura estaba claro: aleccionar a los sacerdotes con el ejemplo de la muerte del santo. Quintana había usado variadas fuentes para componer la escena, algunas de ellas provenientes de grabados de importantes maestros europeos, con una ciudad de Jerusalén que hundía sus raíces en una visión utópica e idealizada de larga trayectoria.

Palabras Clave: Cristóbal Hernández de Quintana, Jerusalén, La Orotava, grabado, Van der Borcht, Wierix, barroco, pintura, Martirio de san Esteban, lapidación.

THE MARTYRDOM OF SAINT STEPHEN OF QUINTANA

AND THE ORIGINS OF THE IDEALISED HOLY CITY

\section{Abstract}

In the last stage of his life, Cristóbal Hernández de Quintana painted the Martyrdom of St. Stephen. The painting was purchased in 1781 to be placed in the main sacristy of the new church of La Concepción de La Orotava, still unfinished. The message of the painting was clear: to teach priests by the example of the saint's death. Quintana had used various sources to compose the scene, some of them coming from engravings by important European masters, with a city of Jerusalem that was rooted in a utopian and idealized vision of long trajectory. KeYwords: Cristóbal Hernández de Quintana, Jerusalén, La Orotava, engraving, Van der Borcht, Wierix, baroque, painting, Martydom of st. Stephen, stoning. 


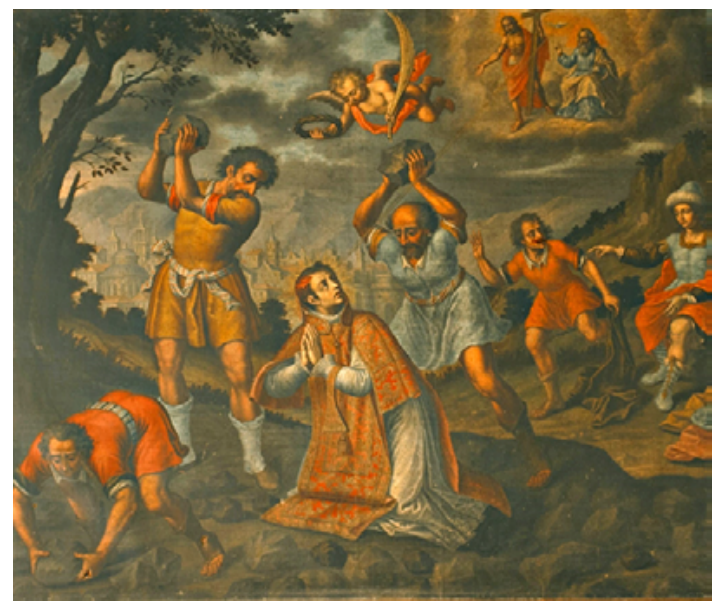

Cristóbal Hernández de Quintana, El Martirio de san Esteban.

Cortesía del Museo de Arte Sacro El Tesoro de la Concepción, La Orotava.

\section{INTRODUCCIÓN}

El 4 de diciembre de 1781, Domingo de Valcárcel cruzó la nueva iglesia de Nuestra Señora de la Concepción de La Orotava con la esperanza puesta en que ya quedaba poco para concluir la que vendría a ser la pieza fundamental del final del Barroco en Canarias y los comienzos del Neoclasicismo. Llevaban ya trece ańos de obras y apenas quedaba terminar la bóveda y la cúpula. Él, como mayordomo, se había empeñado en renovar el nuevo templo y dotarlo de todo aquello que necesitaba. Aquel continente excelso debía acoger también el mejor contenido. Ese día se dirigió al libro de las cuentas de fábrica y anotó que había comprado varios cuadros para colgar en la nueva sacristía. Se había gastado 1730 reales en «ocho quadros que tiene este mayordomo de buenas pinturas para adorno de la nueva Sacristía: asaver uno de Nra. Sra. de la Concepción, otro de San Pedro, Sacandolo Xpo del mar, otro el Martirio de San Estevan con guarnicion dorada, otro retocado de la Virgen de Belén, otro de San Juan Nepomuceno, otro de San Carlos Borromeo, otro de San Felipe Neri y otro de San Cayetano, todos con sus marcos, y el de Ntra Sra de la Concepción con su remate tallado». Como podríamos suponer, el mayordomo

* Licenciado en Historia del Arte. Profesor de la Consejería de Educación, Universidades, Cultura y Deportes del Gobierno de Canarias. E-mail: jesusrodriguezbravo@gmail. com ORCID: 0000-0003-0836-6907. Academia.edu: https://independent.academia.edu/ Jes\%C3\%BAsRodr\%C3\%ADguezBravo.

${ }^{1}$ ARChivo de la parRoQuia de la CONCEPCión de la orotava: Libro III de cuentas de fábrica, f. 134v. El cuadro forma parte actualmente de los fondos del Museo de Arte Sacro El Tesoro de la Concepción, ubicado en las dependencias del propio templo. Se encuentra en la sacristía prin- 


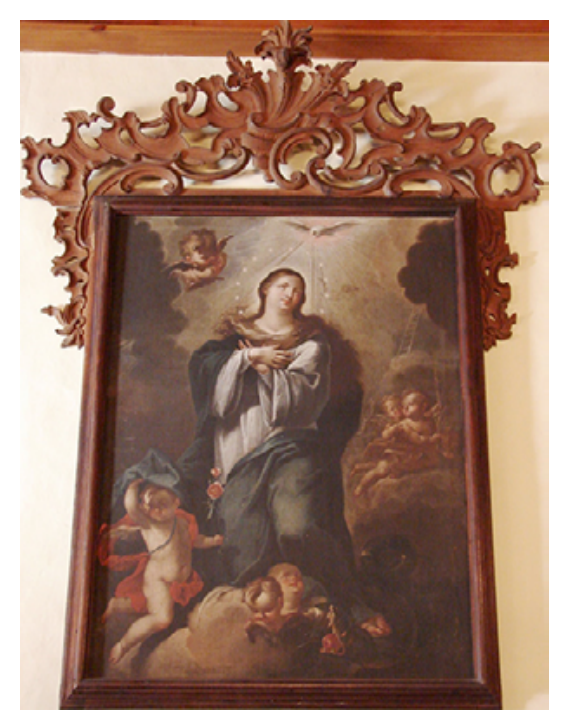

Juan de Miranda, Inmaculada Concepción.

Museo de Arte Sacro El Tesoro de la Concepción.

no escribió a quién se los había comprado ni de qué autores eran. Esos datos se han ido completando con el tiempo y gracias a la labor de sucesivos historiadores. Así sabemos que, sin duda, los de la Inmaculada, con su bello marco de madera tallada, y el Jesús y san Pedro sobre las aguas son obra de Juan de Miranda (1723-1805); los retratos de San Juan Nepomuceno, San Carlos Borromeo, San Felipe Neri y San Cayetano son también suyos pero en ellos intervinieron otras manos, por lo que deben ser adscritos a su taller; la Virgen de Belén, que por la descripción debía ser un lienzo más antiguo, o bien desapareció o se halla en paradero desconocido; y el Martirio de san Esteban es obra inequívoca de Cristóbal Hernández de Quintana (1651-1725)2. Exceptuando la Virgen de Belén, el resto de cuadros sigue colgando de la sacristía principal del templo, doscientos cuarenta años después de que Domingo de Valcárcel apuntara su compra, lo que resulta profundamente elocuente y encomiable.

cipal, sobre el acceso al coro y, aunque su estado general no es malo, sí necesita ser restaurado para devolverle la fuerza de los colores originales.

2 Véanse Martín González, Juan José (1958): El pintor canario Cristóbal Hernández de Quintana. San Cristóbal de La Laguna: Universidad de La Laguna; Martín GonzÁlez, Juan José (1958-II): «Nuevas obras de Cristóbal Hernández de Quintana», en Revista de Historia Canaria, n. ${ }^{\circ}$ 123-124. San Cristóbal de La Laguna: Universidad de La Laguna, pp. 255-257; Rodríguez GonzÁlez, Margarita (1985): El pintor Cristóbal Hernández de Quintana (1651-1725). Santa Cruz de Tenerife: Servicio de Publicaciones de la Caja General de Ahorros de Canarias; y Rodríguez Morales, Carlos (2003): "Quintana. Cristóbal Hernández de Quintana», en Biblioteca de Artistas Canarios, n. ${ }^{\circ}$ 42. Santa Cruz de Tenerife: Gobierno de Canarias. 


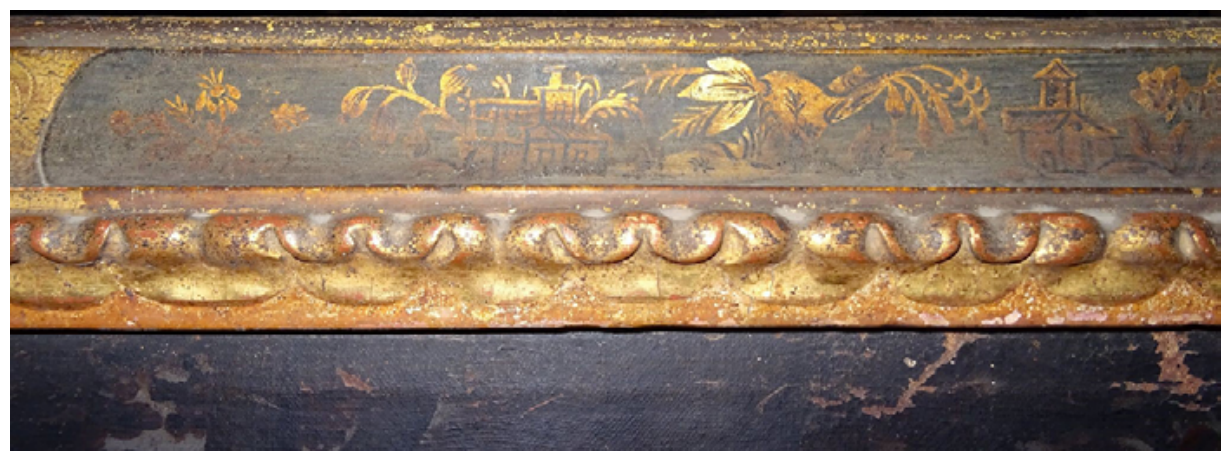

Detalle del marco de El Martirio de san Esteban.

Puestos a analizar la compra hecha por Valcárcel, no resulta ni extrańo ni llamativo que acudiera a Juan de Miranda para decorar la que iba a ser la estancia principal del recinto, reservada a los sacerdotes, y que los temas elegidos tuvieran una intención clara, bajo la idea de ejemplarizar su labor y presentar modelos imitables, desde la figura del fundador de la iglesia hasta los santos vinculados a labores sacerdotales. La presencia de la Inmaculada se sostenía por la propia advocación del templo y la de san Esteban por ser el protomártir y diácono del catolicismo. El mayordomo no pudo ser más contemporáneo, es decir, acudió al que era el principal artista del momento, con la seguridad de que encontraría lo más acorde a la reluciente construcción. Pero ¿por qué no recurrió Domingo de Valcárcel también a Miranda en el caso del Martirio de san Esteban? ¿Por qué compró un cuadro de un maestro ya fallecido como era Quintana y que, como mínimo, había sido pintado sesenta años antes? Debemos suponer que la estima que se tenía hacia el pintor le había sobrevivido de forma singularmente fuerte, un hecho que no es muy frecuente en la historia pictórica de Canarias, en la que el anonimato de los creadores fue numeroso hasta el siglo XVIII. Es decir, un cuadro del maestro tenía aún un peso considerable, sobre todo si se trataba de una de sus composiciones más completas, dentro de las de medio y gran formato.

Sin embargo, nada sabemos de su procedencia, pues solamente conocemos el dato de la compra y su presencia en el mismo lugar desde ese momento. Planteamos en su día que sería una hipótesis muy atractiva que el cuadro hubiese pertenecido al propio Miranda o que al menos se hubiese gestionado a través de él, como una especie de lote de lienzos que incluyeran hasta seis obras suyas, además de esta y la desaparecida Virgen de Belén. No obstante, lo más probable es que estuviese en propiedad de alguien vinculado bien a Miranda, bien a la construcción del templo. $\mathrm{Y}$, en cualquier caso, su propietario debía tenerle el aprecio suficiente como para vendérselo a la fulgurante nueva parroquia, a sabiendas de dónde iba a ser colocado.

Otro aspecto importante es el propio significado de la escena representada, dentro de ese discurso que mencionábamos sobre la labor sacerdotal que pareció tener muy claro el mayordomo a la hora de dotar la nueva sacristía. De este asunto hablaremos a continuación al tratar los orígenes de su iconografía. 
Al margen del propio lienzo, en la obra destaca el marco original, una interesante obra de chinería decorada a base de construcciones, flores e insectos, que nos habla de la época del cuadro, un siglo XviII ya avanzado, ejecutada en dorado sobre fondo negro.

Por lo tanto, el cuadro de Quintana debe ser considerado desde tres ámbitos de estudio: su procedencia incierta, aunque vinculado desde muy antiguo al tempo orotavense; su valor dentro de la producción del pintor, en una etapa evolucionada, como veremos; y sus referentes iconográficos, así como las fuentes utilizadas por el artista.

\section{EL MARTIRIO DE SAN ESTEBAN: ORÍGENES Y REFERENCIAS DE UNA ICONOGRAFÍA}

El Martirio de san Esteban no siempre ha formado parte del catálogo de Cristóbal Hernández de Quintana. Por ejemplo, no aparece entre las obras que el profesor Martín González relacionó con el pintor a finales de los años cincuenta ${ }^{3}$. Sin embargo, sí lo hace en la monografía que la profesora Margarita Rodríguez le dedicó en 1985, seńalando que se trata de uno de los mejores ejemplos para comprobar la inspiración en distintas fuentes grabadas que solía usar el artista ${ }^{4}$. Con posterioridad no ha dejado de formar parte del corpus Quintana, si se nos permite esa expresión, siendo considerada una obra indudablemente suya ${ }^{5}$, algo sobre lo que pretendemos profundizar en este artículo a través del acercamiento a las fuentes y a las formas de trabajar del pintor. A pesar de ello, no siempre ha sido correctamente analizada ni valorada, aspectos que se intentaron suplir en la edición del catálogo del Museo de Arte Sacro El Tesoro de la Concepción, en la conmemoración de su décimo aniversario, de cuya colección forma parte el lienzo ${ }^{6}$.

Decíamos en esa última referencia bibliográfica que el cuadro de Quintana reproduce fielmente el pasaje referido en los Hechos de los Apóstoles ${ }^{7}$ y que el artista tomó prestado de numerosas y diversas referencias modelos humanos, paisajísticos, urbanos y compositivos. De tal suerte que conformó una escena que, si bien se acerca bastante a las composiciones típicas del hecho representado, también introduce elementos propios. En ese libro del Nuevo Testamento se narra cómo Esteban,

3 Martín GonzÁlez (1958), op. cit.

${ }^{4}$ Rodríguez González, op. cit., p. 37.

5 Rodríguez Morales, op. cit.

${ }^{6}$ AA.VV. (2017): El Tesoro. Catálogo del Museo Sacro de la Parroquia de Nuestra Señora de La Concepción de La Orotava. Santa Cruz de Tenerife: Gobierno de Canarias y Parroquia Matriz de Nuestra Señora de La Concepción de La Orotava.

7 «Y arrojándole fuera de la ciudad le apedrearon; y los testigos depositaron sus vestidos a los pies de un mancebo, que se llamaba Saulo. Y apedrearon a Esteban, el cual estaba orando, y diciendo: ¡Señor Jesús, recibe mi espíritu! Y poniéndose de rodillas, clamó en alta voz: ¡Señor, no les hagas cargo de este pecado! Y dicho esto, durmió en el Señor. Saulo, empero, había consentido como los otros a la muerte de Esteban", (Hch 7, 57-59). AA.VV., op. cit., p. 54 y siguientes. 
diácono en la iglesia cristiana primitiva de Jerusalén, fue acusado de blasfemia por los judíos y condenado a morir lapidado. El martirio fue presenciado por Saulo de Tarso, que más tarde se convertiría en san Pablo. Tradicionalmente la escena fue representada en las afueras de las murallas de la ciudad, junto a la puerta de los leones, llamada también de san Esteban.

Como decimos, lejos de copiar literalmente, Quintana tomó elementos que le parecieron interesantes o adecuados a la composición y de su combinación extrajo una nueva imagen. Esto ya lo había hecho antes y se trata de una inspiración propia de otros artistas coetáneos. Tal es el caso de Juan de Sevilla, cuyo trabajo, a la estela de Alonso Cano, trasluce una versatilidad notable. El empleo de estampas con diferentes orígenes y su posterior reelaboración por parte del artista muestra no solo la variedad de imágenes que circulaban en la época sino también su capacidad de asimilación. Por ejemplo, el empleo de grabados de Paulus Pontius, a partir de Anton van Dyck, en los Desposorios misticos de la Virgen (iglesia del convento de San Antón, Granada, 1670) denota la utilización de la fuente y la adaptación a su propia visión de las figuras ${ }^{8}$. En el caso de Quintana, se inspira claramente en grabados de los hermanos Collaert cuando realiza sus tres versiones de los Desposorios de la Virgen (iglesia de la Concepción y colección particular, La Orotava; iglesia conventual de santa Catalina de Siena, La Laguna), pero dotando a los personajes de un estilo propio, o personalizando los rostros y los gestos. A nuestro juicio, la versión en colección particular debe ser considerada una de sus mejores obras. Pontius ya había sido utilizado por Gaspar de Quevedo en su fantástica Piedad (parroquia de San Isidro, más conocida como El Calvario, La Orotava) y a los hermanos Collaert, sobre todo a Adriaen, es frecuente encontrarlos entre las fuentes iconográficas de la época.

$\mathrm{El}$ recurso del grabado para la composición pictórica se remonta a bastante tiempo antes que Quintana, pero tuvo entre los siglos XVII y XVIII un auge extraordinario. Por lo tanto, no debe extrañarnos que un pintor tan prolífico como él acudiese de forma reiterada al mismo. Pero estimamos que cuando el artista se enfrentó a la realización del Martirio de san Esteban ya tenía un bagaje considerable en este asunto, de forma que dominaba y conocía numerosas fuentes, lo que demostraría no solo su capacidad creativa sino también su evolución pictórica. Por esta razón, nos inclinamos a pensar que este cuadro pertenece a su última etapa, cuando sus creaciones van a la par que su fama.

Para alguien que ame la Historia del Arte, adentrarse en los orígenes de una iconografía y comprobar su evolución resulta apasionante. Las representaciones de san Esteban, al tratarse del primer mártir de la iglesia católica, se sitúan casi en los cimientos de la propia religión. Indagar en las primeras imágenes del santo supone concluir que sus atributos y la composición de la escena del martirio, quedaron bien definidas desde sus inicios. Como primer mártir es considerado un personaje pri-

${ }^{8}$ Requena Bravo de Laguna, José Luis (2011): «Nuevas fuentes grabadas en la obra de Juan de Sevilla y Alonso Cano», en Atrio. Revista de historia del arte, n. ${ }^{\circ}$ 17. Sevilla: Universidad Pablo de Olavide, pp. 5-16. 


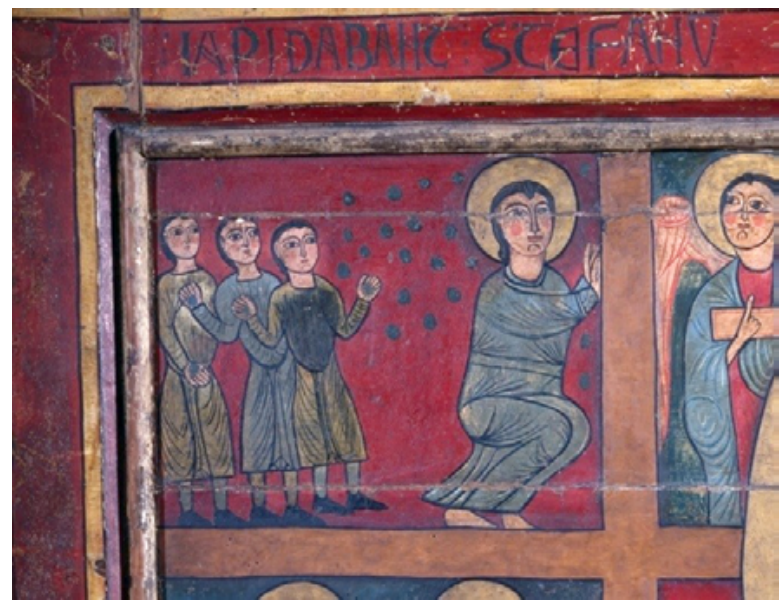

Frontal de Guils (detalle), finales del siglo XIII. Museo Nacional del Prado.

mordial en los orígenes no solo en la Iglesia católica, sino también en la ortodoxa e incluso en la luterana. Suele aparecer vestido de diácono, con la palma del martirio o una iglesia asociadas a su figura. Es frecuente verlo joven e imberbe y relacionado con la lengua griega, ya que, a pesar de ser judío, la hablaba y enseñaba en ella. Son numerosas las pinturas y capiteles que reproducen el momento de la lapidación. Magnífica resulta la pintura mural procedente de la iglesia de Sant Joan de Boí, en Lleida, datada entre los siglos XI y XII, en la que vemos a san Esteban arrodillado con los brazos en alto mientras recibe las pedradas de sus ejecutores y la luz divina procedente de la mano de Dios. Igual de sencillo pero profundamente simbólico es uno de los detalles del Frontal de Guils (Museo del Prado), una pintura al temple datada en el siglo XIII procedente de la iglesia de San Esteban de Guils de Cerdanya (Gerona). A lo largo de la Edad Media, Esteban fue ampliamente representado, no únicamente en el momento de su muerte, sino también como diácono dentro de la iglesia. Por esta razón solía estar ataviado con ropas exquisitamente elaboradas, como las bellísimas que lleva su figura en la pintura procedente de la capilla de Santa María de Gracia (Museo Nacional de Arte de Cataluña). Anterior a estas es la escena de la lapidación que cubre parte de la cripta de la iglesia abacial de Saint Germain de Auxerre en Francia, pintada en el siglo IX y en la que, aparte de las figuras de san Esteban y los sayones, ya podemos ver la representación de Jerusalén como una ciudad medieval amurallada.

A lo largo de los siglos posteriores, los maestros europeos fueron perfeccionando las formas de representar a cada uno de los personajes y, por extensión, también el escenario. Desde Giotto a Rubens o Rembrandt, pasando por Alberto Durero, Fra Angelico o Juan de Juanes, los artistas dieron con un modelo muy fácil de identificar, pero también con una escena que se prestaba a complejos estudios formales, con lo que el tema del martirio del santo fue pintado por casi todos los gran- 


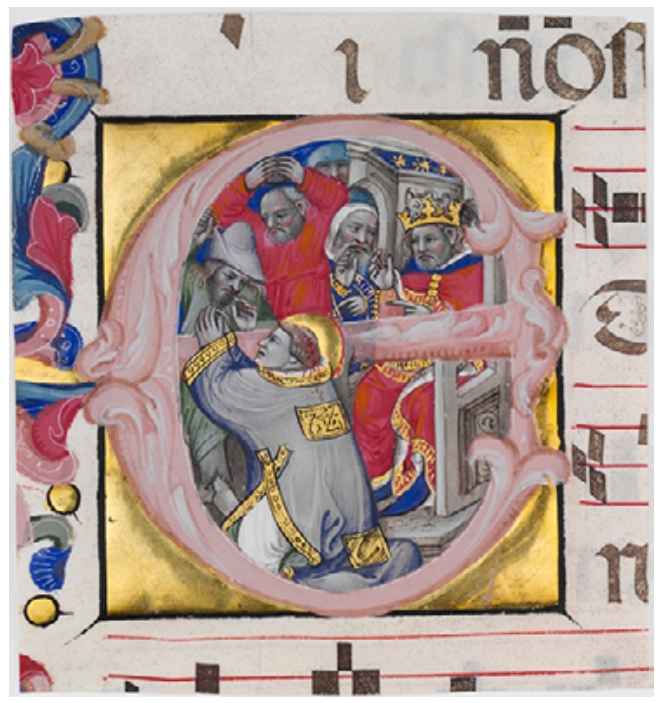

Niccolò di Giacomo da Bologna, The Martyrdom of St. Stephen.

The Metropolitan Museum of Art, Nueva York.

des maestros, especialmente en el siglo xviI. Pero los elementos que conformaban el pasaje de los Hechos de los Apóstoles apenas variaban. En una delicada iluminación de un manuscrito de finales del siglo XIV conservada en el Metropolitan de Nueva York, utilizada para decorar la inicial E y salida del pincel de Niccolò di Giacomo da Bologna, ya se anticipa la que será su iconografía más recurrente: el santo arrodillado en primer término con las manos juntas en oración, los sayones arrojándole piedras, la figura de Saulo a un lado, señalándolo, y una Jerusalén idealizada como fondo arquitectónico. Esta pequeña obra, llena de fuerza y expresividad gracias al uso del color, podría resumir todo lo que llegó después. La escena se repetirá en cuantas representaciones del momento busquemos en la obra de muchos artistas de la época y posteriores. Y esto resultará especialmente importante en la obra grabada, ya que ese será el medio a través del cual se difunda por Europa y América, llegando a las manos de Cristóbal Hernández de Quintana.

Por ejemplo, esto podemos observarlo en un grabado de Israhel van Meckenem (Museo Británico, 1475-1480), en el que los personajes van ataviados a la manera centroeuropea y la ciudad santa podría estar ubicada perfectamente en Renania'. Sin embargo, serán los artistas italianos y flamencos los que establecerán

${ }_{9}$ Israhel van Meckenem (h. 1440-1503) fue un grabador alemán, hijo de otro conocido grabador del mismo nombre, por lo que se le suele llamar «el joven». Reprodujo obras de Durero, Hans Holbein el viejo e invenciones propias. 

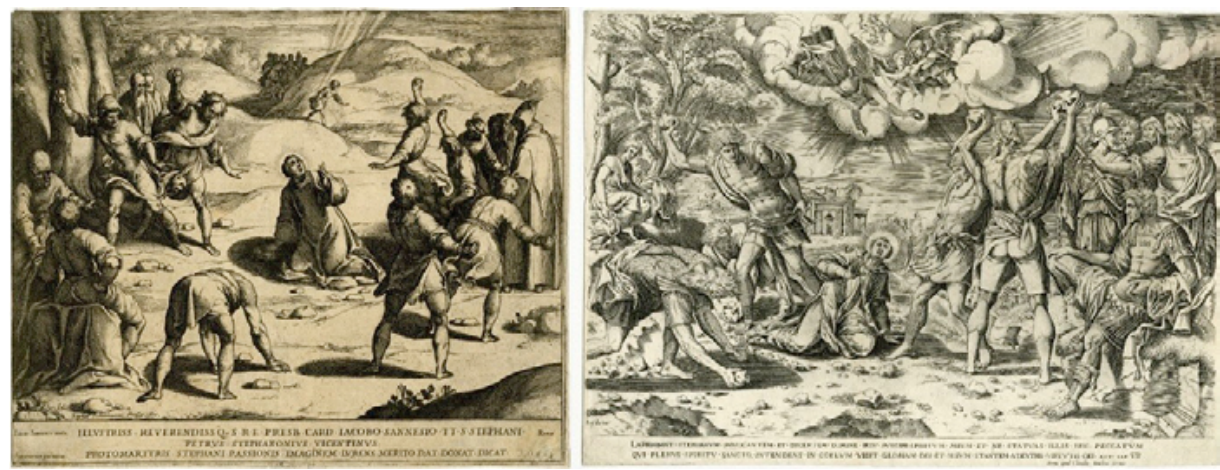

Izquierda: Rafaello Schiaminossi, a partir de Luca Cambiaso, c. 1608.

Derecha: Michelangelo Marelli, a partir de Rafael, c. 1580.

definitivamente la composición del martirio, apenas modificada con posterioridad. En todas estas escenas la figura de san Esteban ocupa el centro de la obra, normalmente arrodillado, con las manos en oración o extendidas y la mirada hacia el cielo, donde frecuentemente vemos a la Trinidad o un rompimiento de gloria. Los sayones también adquieren un gran protagonismo y suelen ser representados por hombres con musculatura, en pronunciados contrapostos; uno de ellos suele estar recogiendo una piedra del suelo, en el primer plano de la imagen y habitualmente de espaldas al espectador. La otra figura que siempre encontramos es la de Saulo, situado con bastante frecuencia en un lateral de la composición, generalmente sentado y vestido con ropas lujosas o militares, acompañado de otros personajes. La escena suele transcurrir en el campo, a poca distancia de la ciudad, que ocupa el fondo de las pinturas o grabados, generalmente cerca de las murallas, como ya hemos dicho. A veces ocurre en el interior de la propia ciudad, como en el caso de la obra de Cherubino Alberti, a partir de Rosso Fiorentino (Museo Británico, 1575); aquí claramente identificada con Roma.

La escena se prestaba a alardes compositivos y formales, con los consiguientes estudios del cuerpo humano, debido a la posición que adquirían los ejecutores al arrojar las piedras. Esta circunstancia se ve muy bien en la obra de Michelangelo Marelli, a partir de Rafael, fechada hacia 1575-1580 y en la que, al margen de encontrar todos los elementos arquetípicos, el autor aprovecha para desarrollar posturas algo forzadas, dotando a la escena de la teatralidad que la caracteriza. El propio Rafael hará gala de esta circunstancia en el magnífico cuadro de la lapidación del santo que hoy podemos ver gracias al tapiz realizado por Jan van Tieghem y Frans Gheteels a mediados del siglo xvi, como parte de las colecciones del Palacio Real.

Una de las virtudes del Martirio de san Esteban de Quintana es el haber conseguido aunar distintos elementos en un solo cuadro. En la composición hay dos escenas o, mejor dicho, dos partes de una misma escena, pero tomadas de fuentes distintas. En un primer término, vemos la figura del santo arrodillado, con las manos juntas en oración y la cabeza ladeada mirando a la Trinidad, que aparece 
en la parte superior derecha en un gran rompimiento de gloria. Esteban ocupa la centralidad del lienzo pero no es el único protagonista. A la izquierda, uno de sus ejecutores recoge una gran piedra del suelo, obligando al espectador a fijarse en su postura algo forzada. A ambos lados del santo otros dos sayones están a punto de arrojarle sendas piedras: el de la izquierda es una de las mejores figuras pintadas por el artista en posiciones de movimiento y desarrolla el contraposto que antes mencionábamos y que se asocia a esta escena; el de la derecha está menos logrado y presenta un error anatómico en los hombros, pero que ya se aprecia en la estampa original, como veremos en el siguiente apartado. Esta parte de la lapidación transcurre sobre un espacio delimitado por la superficie del suelo, sobre el que aparecen otras grandes piedras y que se extiende hasta el arranque del árbol que enmarca la parte izquierda del cuadro. Toda esta zona está en sombra, lo que acrecienta el efecto de profundidad, una de las características de la obra; tal vez en la que Quintana consiguió provocarla de manera más acertada. La otra parte de esta composición transcurre a la derecha. Allí aparece Saulo, ataviado con ropas militares a la manera romana, con capa y armadura, lo que se identifica con los sucesos que tuvieron lugar en su etapa de juventud, que estuvo ligada a la persecución de los cristianos, antes de su conversión. Tal y como se relata en los Hechos de los Apóstoles, Saulo fue testigo de la lapidación de Esteban, pero se mantuvo al margen, como un mero espectador. Aquí lo vemos indicando a un cuarto sayón el lugar donde se encuentra el que va a ser ajusticiado, con los mantos del resto de los ejecutores a sus pies. Este cuarto sayón se está despojando de la capa para participar también en la lapidación. Al tiempo, esta segunda escena transcurre también sobre la superficie del suelo, pero ya no está en sombra, sino que se prolonga hacia el fondo del cuadro, uniéndose al paisaje. Por otro lado, san Esteban mira directamente a la Trinidad, a la que se une con una línea de luz que el pintor traza delicadamente y que termina en el Espíritu Santo. En el eje central del lienzo un ángel porta la palma del martirio y la corona, colocada en la perpendicular de la cabeza de Esteban. El paisaje se extiende hacia el fondo del cuadro, en un ejercicio de perspectiva del que Quintana sale airoso. Es probablemente la obra en la que mejor atrapa el efecto de la cordillera de montańas que recorren la pintura de derecha a izquierda. En ese espacio sitúa a la ciudad de Jerusalén, pero de esto hablaremos más detalladamente en el siguiente apartado. En suma, Quintana consigue desarrollar la escena del martirio de manera virtuosa, recalcando sobremanera el ambiente creado por el paisaje y la profundidad. La gama de colores se acerca mucho a su producción, destacando el contraste de los rojos y ocres con los azules y los blancos.

Los rostros de los personajes, las formas y la vestimenta recuerdan a otras obras del artista, lo que demuestra la identidad de su estilo, cuya estela pervivirá en la obra de otros pintores que lo seguirán copiando mucho después. San Esteban viste la dalmática propia de su función. Esta y la construcción de su cabeza son muy similares a las del San Lorenzo de la iglesia de San Antonio Abad de La Matanza, una obra atribuida a Quintana en la que el pintor incluye un fondo arquitectónico que se desarrolla más notablemente en uno de los laterales. La estancia en el cuadro de La Matanza recuerda a otras composiciones suyas, en las que utiliza la perspectiva y la sucesión de espacios para conseguir cierta profundidad, dotando a la pintura 


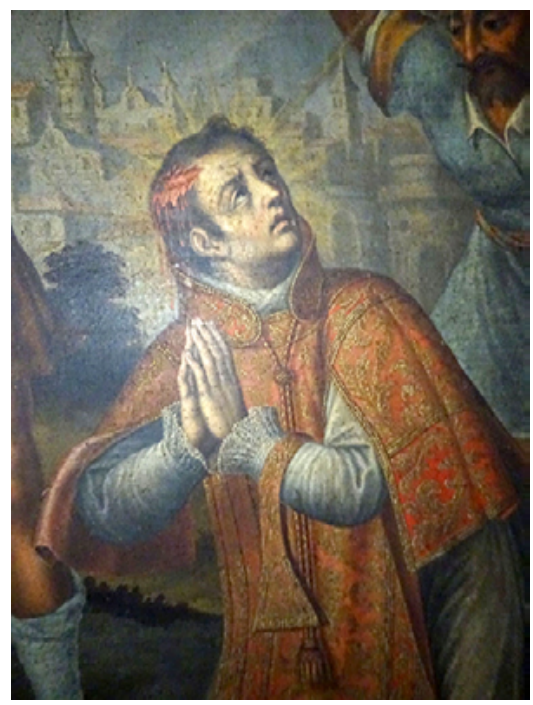

Cristóbal Hernández de Quintana, El Martirio de San Esteban (detalle).

de aire alrededor de la figura, a veces ocupado por un rompimiento que nos habla de la influencia de Gaspar de Quevedo.

Para el ángel central Quintana usó exactamente el mismo modelo que en la Santa Bárbara que corona el retablo de san José de la iglesia de santo Domingo de La Laguna ${ }^{10}$, salvo que en nuestro caso es aquel el que porta la palma del martirio. La figura del angelito parece estar inspirada en grabados de Aegidius Sadeler, como el que aparece en el Martirio de San Sebastián, que parte de una obra del pintor manierista veneciano Palma el Joven. Pero sin duda, guarda relación también con los de las puertas del comulgatorio y el confesionario del convento de Santa Catalina de Siena de La Laguna. Da la sensación de que se tratara de uno de ellos, pero desplazado a otra escena bíblica. Y resulta muy similar al modelo usado en las dos versiones de su San Pio Ve incluso al que corona a Santo Domingo en el cuadro homónimo atribuido a Gaspar de Quevedo, en la misma parroquia en la que se encuentra el Martirio de San Esteban. Esto nos habla por un lado de su autoría y por otro de las maneras de trabajar de los artistas de la época, acostumbrados a usar recursos similares.

${ }^{10}$ Rodríguez Morales, op. cit., p. 118. 


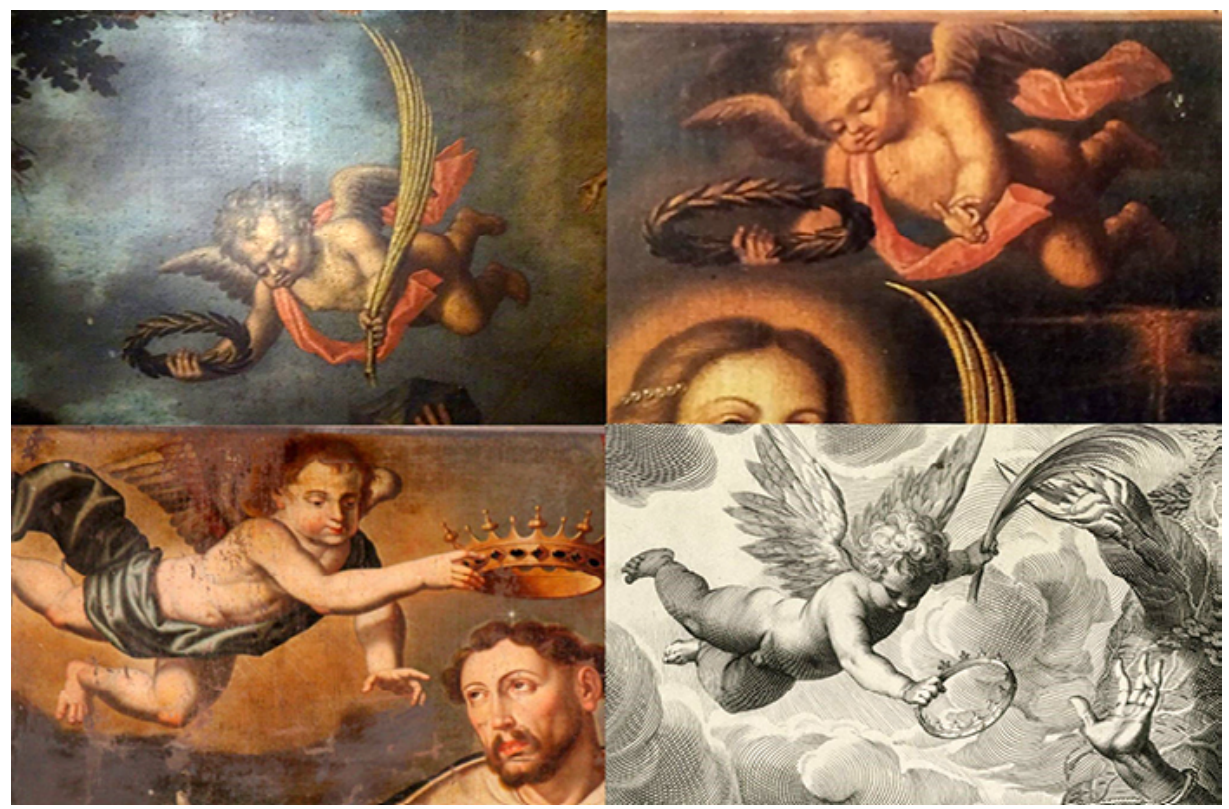

De izquierda a derecha y de arriba a abajo: Cristóbal Hernández de Quintana, El Martirio de San Esteban (detalle); Santa Bárbara (detalle); Gaspar de Quevedo, Santo Domingo de Guzmán (detalle); Aegidius Sadeler, Martirio de San Sebastián (detalle), c. 1600.

\section{LOS HERMANOS WIERIX, LA BIBLIA VAN BORCHT, QUINTANA Y LAS IMÁGENES DE JERUSALÉN}

Como dice Jacopo della Voragine, Esteban era un ejemplo a seguir, el primero en padecer en nombre de Cristo. Para el sacerdote que entrara en la sacristía del recién inaugurado templo de la Concepción, a partir de 1788, contemplar el cuadro de Quintana también suponía asumir que aquel diácono, uno de los siete nombrados por los apóstoles, había muerto por ser constante en la predicación y defenderse con la palabra. Y había que imitarlo y admirar la fuerza de su sufrimiento. Quintana había sabido plasmar aquella idea uniendo, como solía hacerlo, imágenes que ya habría consultado e incluso utilizado. La manera más directa a través de la cual el pintor pudo acercarse a la forma de representar el martirio del primer mártir tuvo que ser la llamada Biblia Sacra. Se trataba de la versión en un latín más accesible de la Biblia en hebreo y griego y que es conocida como la Vulgata. Sus ediciones y la fuerza de su difusión son tales que resultaría prolijo e innecesariamente extenso insistir en las numerosas versiones ilustradas que se distribuyeron a lo largo del territorio europeo y americano. Lo cierto es que la Biblia Sacra se convirtió en el medio más eficazmente usado de difundir los textos sagrados. La inclusión de grabados y estampas para ilustrar determinados pasajes sirvió de desarrollo del arte de gran- 


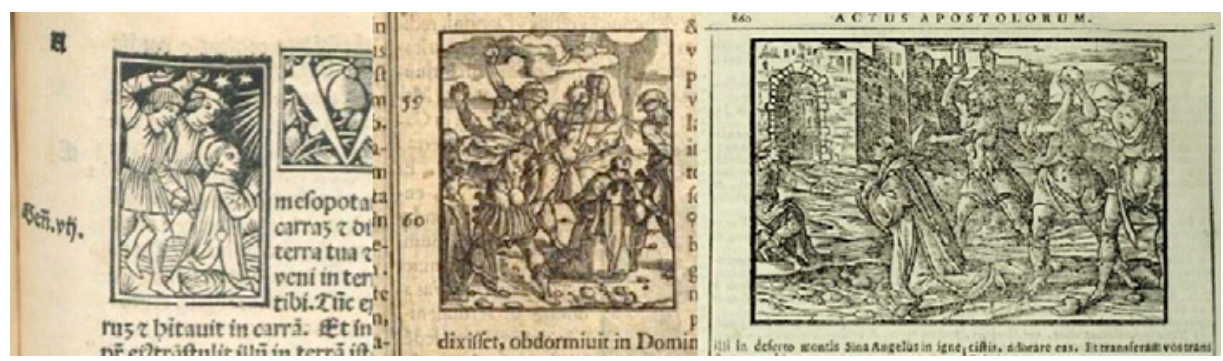

Biblia sacra (detalles). Ejemplares de 1516, 1603 y 1720.

des maestros grabadores, sobre todo de los Países Bajos. El esmero, la precisión y la belleza de muchos de esos trabajos, bien fueran creaciones propias o reproducciones de obras de otros artistas, han sido objeto de interesantes estudios iconográficos. Y la lapidación de san Esteban siempre se encuentra entre los más recurrentes en esas publicaciones.

Las biblias sacras no eran todas iguales, ni tenían la misma calidad a la hora de reproducir un grabado. Por eso, es frecuente encontrar ejemplares con pequeńas ilustraciones, muy sencillas y elementales, pues ni el presupuesto ni los medios daban para resultados más logrados. Pero en ese mar de publicaciones hay verdaderas joyas, algunas salidas de maestros frecuentemente usados por Quintana y la mayoría de los maestros de la pintura de la época e incluso posteriores. Hablamos de Johan Sadeler, Anton, Johannes o Hieronymus Wierix o Pieter van der Borcht.

Como sabemos, la copia de grabados era habitual entre todos los artistas de los siglos XVII y XVIII. Lejos de nuestra perspectiva actual, esta práctica se veía como legítima y recomendable. Pero el traslado de una imagen que solía ser de pequeñas dimensiones a un formato mayor conllevaba problemas que solo aquellos artistas con mayores habilidades y experiencia eran capaces de resolver con maestría ${ }^{11}$. Entre estos maestros era frecuente utilizar elementos aislados de aquellas estampas que se combinaban con otras o se situaban en contextos distintos, sobre todo respecto al fondo de la escena. De tal forma que la imagen obtenida se inspiraba en la original pero no la copiaba literalmente.

A mediados del siglo Xvi la ciudad de Amberes se convirtió en un centro de producción de estas biblias ilustradas con grabados de Maarten van Heemskerck o Maerten de Vos. De hecho fue Johan Sadeler el que reprodujo una pintura de este último sobre el martirio de san Esteban en la que hay elementos que Quintana usará en varios de sus cuadros, especialmente la representación de la Trinidad o la figura de Saulo. Por otro lado, a finales de ese siglo estas obras ilustradas vivieron una espe-

11 Pérez Morera, Jesús (1992): «Apuntes para un estudio de las fuentes iconográficas en la plástica canaria», en Revista de Historia Canaria, n. ${ }^{\circ}$ 176. San Cristóbal de La Laguna: Universidad de La Laguna, pp. 207-229. 
cie de revolución con la publicación de las Evangelicae historiae imagines del jesuita Jerónimo Nadal, impresa por Plantin y acompañada con grabados de Pieter van der Borcht $^{12}$. Las imágenes de este último ilustrarían igualmente la famosa Imagines et figurae bibliorum, una magnífica edición en la que ocupaban casi la extensión del folio. Esta obra, escrita en tres idiomas (latín, neerlandés y francés), está considerada una de las ediciones más interesantes de las ejecutadas por Borcht. Junto a Hendrick Jansen van Barrefelt, las sesenta planchas del grabador holandés ilustraban escenas escogidas del Antiguo y Nuevo Testamento ${ }^{13}$. El trabajo de Borcht fue tan conocido y difundido que sus planchas fueron reutilizadas en otras publicaciones, como en la Emblemata Sacra o la Biblicae Historiae y fuera de Amberes, tanto en Ámsterdam como en Alemania. Su éxito fue tal que sus creaciones fueron copiadas y usadas por otros artistas hasta el siglo XVIII. Y, como señalan Hans y Ursula Mielke, sus grabados sirvieron enormemente para difundir las ideas religiosas que represen$\operatorname{taban}^{14}$. De hecho, durante mucho tiempo fueron conocidas pero no identificadas porque en las primeras ediciones de la Imagines et figurae Bibliorum los nombres de los autores y las fechas fueron cambiados conscientemente, ya que los comentarios que acompañaban a las ilustraciones podían no ser del todo correctos para la época. Posteriormente las planchas de las imágenes y de los textos se separaron y las primeras se siguieron utilizando para ilustrar otras biblias posteriores. Aún así, Borcht continuó con su trabajo a un ritmo frenético, de tal forma que hoy se le considera uno de los grandes y más longevos grabadores de los Países Bajos.

Por ejemplo, en las ediciones de la obra Humanae Salutis Monumenta de Benito Arias Montano, una colección de odas dedicadas a personajes de la biblia, publicadas originalmente en la imprenta de Cristóbal Plantin en 1571 en Amberes, los textos también iban acompańados de grabados salidos de las manos de Pieter van der Borcht y Johannes y Hieronymus Wierix, entre otros. Varias de estas imágenes incluían fondos arquitectónicos compuestos a base de edificios de influencia clásica y elementos medievales y en ellas podemos ya apreciar los elementos que se repetirán, a modo de amalgama en el cuadro de Quintana. Lógicamente la pintura se apropiaba de modelos anteriores. Es el caso del Martirio de san Esteban de Juan de Juanes que conserva el Museo del Prado, un óleo sobre tabla fechado entre 1555 y 1562 en el que se aprecian los modelos que luego van a presentar las tres figuras principales: un san Esteban arrodillado vestido de diácono con las manos juntas que mira hacia el cielo y dos sayones que van a apedrearlo de forma violenta. La arqui-

12 Stronks, Els (2015): «The diffusion of illustrated religious texts and ideological restraints", en Texts, Transmissions, Receptions. Modern Approaches to Narratives. Leiden: Brill. https:// www.jstor.org/stable/10.1163/j.ctt1w76wgh.

${ }^{13}$ Hamilton, Alastair (1981): «From familism to pietism. The fortune of Pieter van der Borcht's biblical ilustrations and Hiël's commentaries from 1584 to 1717», en Quarendo, volumen 11. Leiden: Brill, pp. 271-301.

14 Mielke, Hans y Mielke, Ursula (2005): «Peeter Van Der Borcht: Book Illustrations», en New Hollstein Dutch \& Flemish etchings, engravings and woodcuts, 1450-1700. Ámsterdam: Sound \& Vision Publishers y Rijksmuseum. 
tectura que aparece en el fondo de esta pintura se inspira en motivos clásicos tomados de Rafael. Es decir, ni Borcht ni los Wierix, ni por supuesto Quintana, estaban inventando nada, pero en sus manos sí estaba la capacidad de crear nuevamente a partir de aquellos modelos. En eso reside su originalidad.

Las representaciones del martirio que incluían muchas de esas biblias sacras reproducen los elementos típicos a los que hemos aludido anteriormente, de tal manera que resultaría fácil para Quintana haberlos copiado. De hecho, su análisis demuestra hasta qué punto la escena estaba consolidada en cuanto a qué elementos debían aparecer sin falta. Pero el artista no utilizó ninguna de esas escenas, que por otra parte eran bastante esquemáticas por el tamaño al que debían ser reproducidas, como ya hemos señalado. Quintana acudió a una de las mejores fuentes de la época, la llamada Biblia van Borcht, uno de cuyos ejemplares se conserva en el Museo Municipal de Bellas Artes de Santa Cruz de Tenerife ${ }^{15}$.

Pieter van der Borcht era amigo de Cristóbal Plantin y de Benito Arias Montano. Tras realizar los grabados de los Monumenta, ilustró los pasajes de las Imagines et figurae Bibliorum. Como hemos dicho, las planchas fueron reutilizadas una y otra vez para acompañar a los textos bíblicos y publicadas no solo en impresores de Amberes sino también de Holanda. El ejemplar conservado en Tenerife fue editado en Ámsterdam en 1613, incluyendo las estampas que ya se habían utilizado en obras anteriores.

Esta biblia es una joya bibliográfica. Como decimos, está editada en la ciudad holandesa, en la imprenta de Michiel Colijn, bajo el título Bibelsche Figueren, ofte Afbeeldingen van al de Gedencweerdige Historienende Andere Gheschiedenissen, des Nievwen Testament (Figuras bíblicas, o Ilustraciones de todas las historias y eventos más notables del Nuevo Testamento) ${ }^{16}$. Michiel Colijn, conocido también como Colijn de Thovoyon, fue un editor, impresor y librero activo en Ámsterdam al menos entre 1584 y 1637, cuya imprenta estaba en la Op't Water, la actual Damrak o bolsa de Ámsterdam, un canal ubicado en el centro de la ciudad y que desde antiguo fue una vía de comunicación comercial. Su actividad como editor no fue grande pero sí importante. Colijn publicó cuatro series de biblias entre 1613 y 1617, las ilustradas con grabados de Borcht y otras con imágenes a partir de los frescos de Rafael en la Logia Vaticana. Antes que la Biblia van Borcht había publicado en $1610 \mathrm{Het}$ reys-gheldt van de wterste of laetste reyse, del humanista Nathan Chytraeus; en 1611 imprimió la Polemographia Avriaco-belgica, de Baudartius, sobre la guerra de los ochenta años; en 1612 una edición de la Cosmographia, del astrónomo y matemático Gemma Frisius, sobre la aplicación de la trigonometría en la navegación marí-

${ }_{15}$ Agradezco al personal del Museo las facilidades puestas para la consulta de esta joya bibliográfica. En especial a Silvia Arteaga y Katarzyna Zych, cuyos conocimientos y respeto por el documento han sido muy enriquecedores y alentadores.

${ }^{16}$ Figuras biblicas, o Ilustraciones de todas las historias y eventos más notables del Nuevo Testamento. Con una breve exposición alegórica o espiritual de la misma, muy útil para todo tipo de caballeros. Corregido y ampliado con varias láminas. Texto completo del título, traducido del neerlandés antiguo, de la primera página conservada en la edición del Museo. 


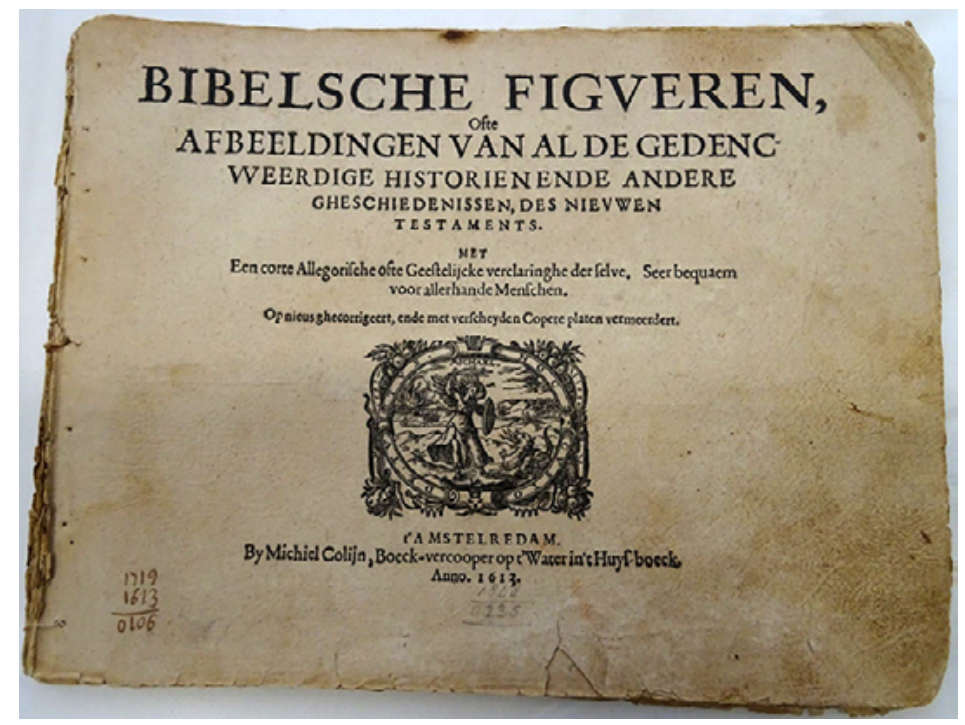

Michiel Colijn (editor) y Pieter van der Borcht (grabador), Bibelsche Figueren, Ámsterdam, 1613. Museo Municipal de Bellas Artes de Santa Cruz de Tenerife.

tima. Posteriormente publicó obras muy interesantes como Les guerres de Nassau, de Guillaume Baudart, que vio la luz en 1616 y trataba los conflictos bélicos bajo el reinado de Felipe II en los Países Bajos, ilustrada con grabados de Franz Hogenberg; y Oost-Indische en West-Indische voyagien, un relato de los viajes de Houtman, van Neck, Spilbergen, van Noord y otros, reeditados entre 1617 y 1619; entre muchas otras obras salidas de su imprenta ${ }^{17}$.

En 1613 publicó la que denominamos Biblia van Borcht, una versión más pequeña de la Emblemata Sacra que había sacado Plantin en 1581, con las planchas de van Borcht y los textos en neerlandés, de la que hará varias ediciones entre ese año y 1617. El ejemplar conservado en el Museo Municipal de Bellas Artes de Santa Cruz se corresponde con la primera de las reediciones, lo que la hace especialmente rara, ya que se trata de un ejemplar publicado para los Países Bajos, en el marco de los movimientos protestantes, de los que Colijn fue un firme defensor. Por lo tanto, resulta curioso que esta versión fuera utilizada para representar escenas propias de la iglesia católica en un lugar como España, donde la reforma protestante fue tan combatida. Probablemente el hecho de que los textos estuviesen en neerlandés ayudó a que pasara más desapercibida. Aunque su estado de conservación no es el más

17 Para la obra de Michiel Colijn seguimos a Molhuysen (2008): Nieuw Nederlandsch biografisch woonderboek. Deel 10. Leiden: Dbnl. 
adecuado, aún puede apreciarse la calidad del papel y la potencia de la impresión de los grabados, así como el detallismo tan propio de Borcht, cuya firma aparece en muchos de ellos. También en la primera página podemos ver el precioso emblema de Colijn, un arcángel san Miguel luchando contra el dragón bajo la leyenda $H o c$ custo de tu tus (Para evitar que te quemes).

La historia de este ejemplar resulta muy ilustrativa de las maneras de trabajar de los artistas de la época. Gracias a una anotación escrita en uno de los cartones que hacían las veces de portada y que también la protegían, sabemos que fue donada al museo en 1917 por Teodomiro Robayna (1864-1925), uno de los fundadores y director de la institución, artista e hijo del también pintor Gumersindo Robayna. En el texto señala que la recibió de su padre, que a su vez la había recibido de otro pintor llamado Manuel Cárdenas y que a este le había llegado a partir de Juan de Miranda, a quien había pertenecido el ejemplar ${ }^{18}$. Es posible, como se ha señalado en alguna ocasión, que Miranda adquiriese la biblia en una de sus estancias en la Península, pero si tomamos la referencia de que Quintana tuvo acceso a ella, su procedencia sería bien distinta. Estaríamos ante una obra que pasó de mano en mano, pero siempre en el ámbito de los artistas, como fuente de inspiración para su trabajo. E incluso, dada la fecha de impresión de este ejemplar, no resulta difícil encontrar un hilo conductor anterior a Quintana. En cualquier caso, es significativo que el libro se transmitiese a través de las manos de tantos pintores y en ese sentido es evidente que su estado de conservación demuestra el uso al que fue sometida. A esto añadimos dos datos curiosos que pueden verse en la primera página. Se trata de dos anotaciones: la primera hecha a tinta en el margen inferior izquierdo y que consiste en una resta de los números 1719 y 1613 con el consiguiente resultado de 106; la segunda está hecha a lápiz justo bajo el año de edición y es una segunda resta de los números 1848 y 1613, con el resultado de 235. En ambos casos alguien dejó constancia escrita del cálculo de la antigüedad de la biblia.

Arias Montano valoraba la calidad de los dibujos que van der Borcht había hecho para la llamada Biblia Políglota, que él mismo había realizado. Como dice Silvaine Hänsel, la cuidada ejecución de los paisajes en la obra de Borcht enlazaba con los trabajos de Bruegel y que en el primero se caracterizan por la variedad ${ }^{19}$. Curiosamente, uno de los mayores valores del cuadro orotavense de Quintana es precisamente el paisaje, una característica que no es demasiado frecuente en el pintor y que encuentra cierto paralelismo con otro lienzo que él mismo se encargó de retocar, aunque lo más correcto sería decir que lo reformuló. Nos referimos a $\mathrm{La}$ familia de la Virgen (catedral de Santa Ana, Las Palmas de Gran Canaria), de Juan de Roelas y que Quintana restauró en 1724, según reza en el propio cuadro, a ini-

${ }_{18}$ Miranda utilizó este mismo grabado para su Expulsión de los mercaderes del templo y otros de la misma edición para uno de los lienzos que forman el Vía Crucis de la Orden Tercera de Santa Cruz de Tenerife.

${ }^{19}$ Hänsel, Silvaine (2016): Benito Arias Montano: humanismo y arte en España. Huelva: Universidad de Huelva, p. 209. 


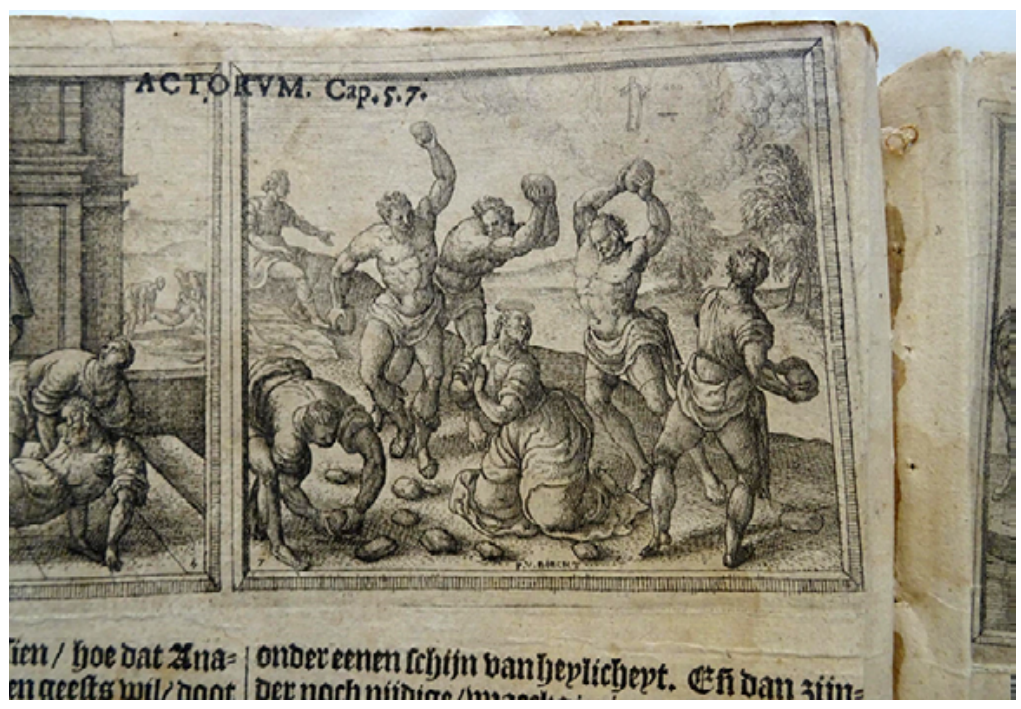

El Martirio de san Esteban, Biblia Van Borcht.

Museo Municipal de Bellas Artes de Santa Cruz de Tenerife.

ciativa del canónigo Manuel Álvarez de Castro; un Quintana ya de 73 ańos ${ }^{20}$. El fondo paisajístico de la composición y los colores son de lo poco que probablemente se conserve de Roelas, pero la paleta y el recurso del árbol lateral que enmarca el paisaje presentan similitudes con Quintana. Lo mismo sucede con el paisaje que acompaña a La Piedad de Gaspar de Quevedo, en lo referente a este recurso.

Es indudable que Quintana obtuvo los modelos de los sayones para su cuadro de los grabados de Borcht que se incluían en algunas de sus biblias, no solo en la conservada en Santa Cruz. Pero solo utilizó tres de ellos; en la estampa del Museo de Bellas Artes de Santa Cruz son cinco. Los demás no le interesaron porque le molestaban para poder poner en esa parte la figura de Saulo, cuya inspiración toma del mismo grabado, aunque con probabilidad pudo ver otras obras del propio Borcht, de Jacques Callot o Jan Sadeler y de algunas obras impresas italianas. La figura del segundo sayón es, probablemente, una de sus mejores construcciones anatómicas, destacando el trabajo de la cabeza, de gran rotundidad. Si comparamos este personaje con su homónimo en la Biblia Van Borcht santacrucera vemos que no guarda demasiada relación. Sin embargo, si se la compara con otra de los grabados del artista para las ediciones de finales del siglo Xvi, coincide casi al milímetro. El modelo volverá a utilizarlo en las Ánimas del Purgatorio de la catedral de La Laguna, concretamente en los personajes que esperan purgar sus culpas en la parte baja del cuadro,

20 Martín González (1958), op. cit. 

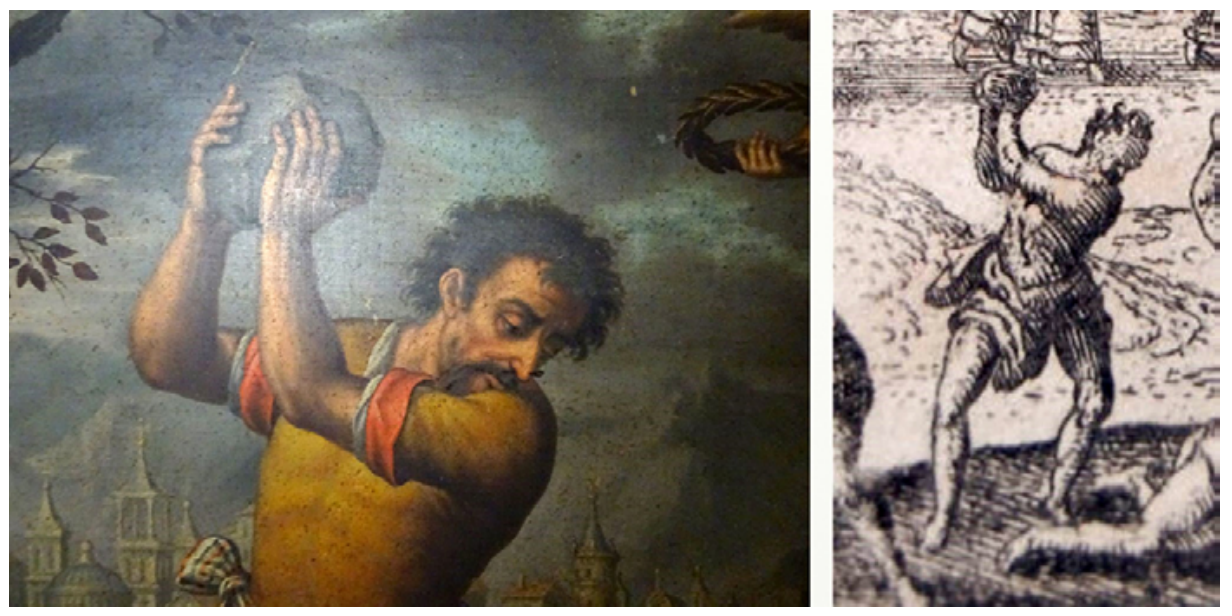

Izquierda: sayón en El Martirio de san Esteban. Derecha: detalle de una de las planchas de Borcht para la edición de 1582 del editor Jacob van Royen.

y que se ha relacionado con la representación iconográfica del tema de la Virgen de Candelaria entre guanches, aunque el ejemplo orotavense resulta de mucha mayor fuerza $^{21}$. Como puede apreciarse, Quintana toma el modelo, la postura o la estructura general de la figura pero es capaz de imprimirle su propio sello, ya que el grabado no es tan detallista. De esa manera consigue imprimir a su sayón su impronta personal, demostrando su habilidad para inspirarse sin copiar literalmente.

El sayón central de Quintana presenta un error anatómico a la altura de los hombros, que parecen luxados o estar pintados desde atrás; pero, al contrario de lo que se ha afirmado, no se trata de un problema del pintor orotavense, pues el mismo fallo se halla en el grabado de Borcht. Lo que no hace Quintana es resolver ese desajuste en la anatomía del personaje; y en esto hay que decir que el artista no era precisamente especialista. Otro detalle que cambia es la vestimenta, más cercana a la utilizada por él en otros muchos de sus lienzos. La figura de san Esteban tampoco la toma directamente del dibujo de Borcht, prefiriendo las referencias iconográficas de las citadas biblias sacras, aunque, a diferencia de la mayoría de ellas, coloca las manos del santo unidas y no extendidas, como solía ser habitual, algo en lo que se acerca al grabado santacrucero. En eso recuerda a las estampas de van Meckenem y van Heemskerck. Las figuras que componen la Trinidad están directamente toma-

${ }^{21}$ Rodríguez Morales, Carlos (2009): «Espejos marianos. Retratos y retratistas de la Candelaria», en Vestida de sol. Iconografía y memoria de Nuestra Señora de Candelaria. Santa Cruz de Tenerife: Cajacanarias. Obra social y cultural, p. 33. 


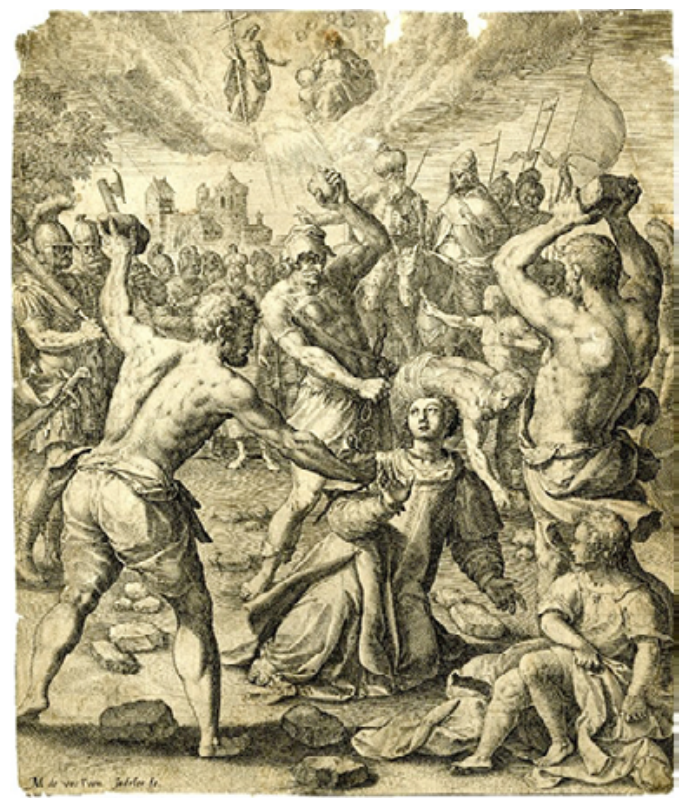

Jan Sadeler I, a partir de Maerten de Vos, El Martirio de san Esteban, c. 1580.

das de Adriaen Collaert y Jan Sadeler, a partir de Maerten de Vos, y que de nuevo utilizará en las Ánimas del Purgatorio de la catedral lagunera.

Uno de los elementos fundamentales del Martirio de san Esteban es la presencia de la ciudad de Jerusalén en el fondo de la composición. La ciudad santa había sido el centro del mundo durante mucho tiempo. Incluso cuando los mapas comenzaron a incluir los nuevos territorios conquistados en América, la urbe siguió ocupando el centro de las representaciones. No obstante, la imagen que se tenía de ella era el resultado de fabricar una especie de mito, de lugar mágico e idealizado. Y al no conocerla directamente, se la representaba como cualquier otra ciudad europea, incluyendo en esta visión los órdenes clásicos que se asociaban a la gran arquitectura, de tal forma que muchas veces se parecía más a Roma que a cualquier ciudad oriental. El conocimiento progresivo de la Jerusalén real, gracias sobre todo a los libros de viajes de quienes peregrinaban a Tierra Santa, ayudó a construir una imagen más cercana a la realidad, pero nunca dejó de tener ese componente idealizado ${ }^{22}$. En el plano estrictamente estético, Jerusalén fue representada de dos formas distintas, aunque no separadas de una misma idea. La primera de estas opciones

22 Sobre este tema véase AA. VV. (2017): Urbs Beata. Hierusalem. Los viajes a Tierra Santa en los siglos XVI y XVII. Madrid: Ministerio de Educación, Cultura y Deporte y Biblioteca Nacional de España. 

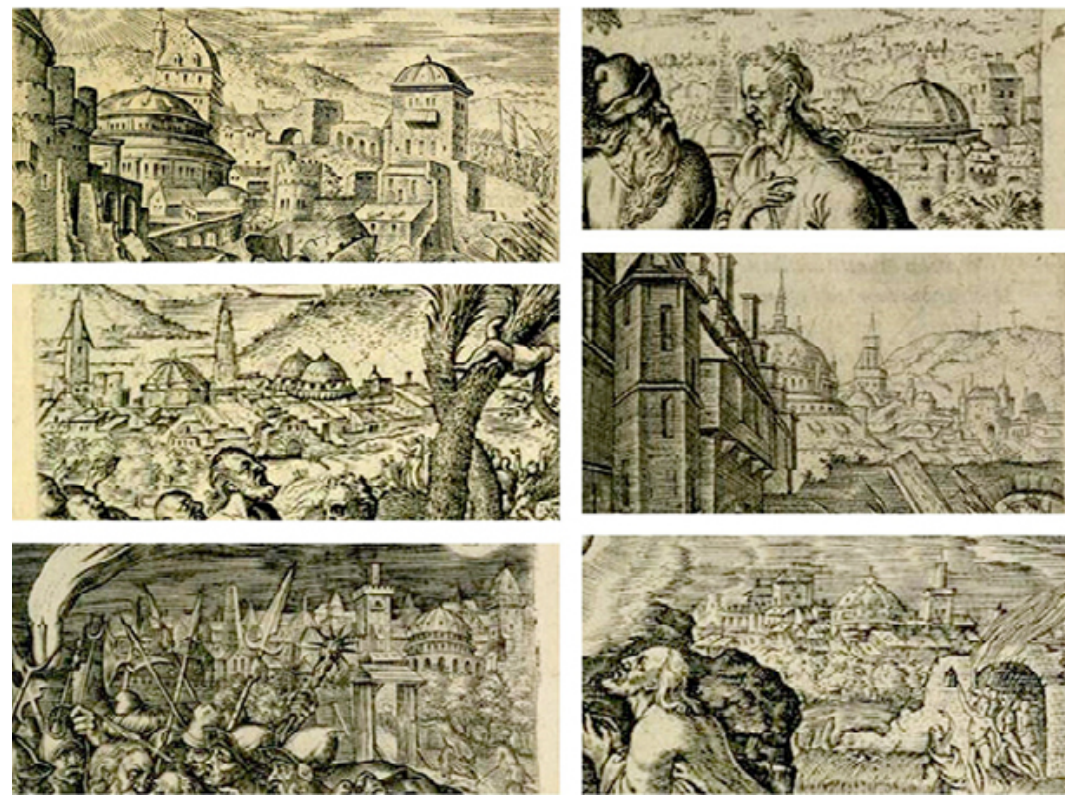

Pieter van der Borcht, detalles de los grabados de las Humanae Salutis Monumenta.

fue la de presentarla como una ciudad abigarrada, repleta de edificios y torres. Esta fue la elegida por Quintana. La segunda tendencia, muy frecuente en grabados del siglo XVI, era la de una ciudad en damero, perfectamente cuadriculada, amurallada y con el templo en su centro. Así aparece en obras, entre muchos otros, de Maerten de Vos. El modelo usado por nuestro pintor puede verse en grabados de Sadeler, Collaert, Maerten de Vos, van Heemskerck y los citados hermanos Wierix pero especialmente en las creaciones de Pierter van der Borcht. En todos ellos las casas y edificios mezclan estilos, de tal forma que podemos ver arquitectura clásica junto a elementos medievales y, en casos más desarrollados, cierta influencia oriental. Una ciudad representada como una suma de bloques cúbicos, torres, puertas, murallas y el templo de Jerusalén con su cúpula, generalmente en el centro.

La segunda tendencia presenta una ciudad perfectamente planificada. Esta representación sería la denominada Jerusalén celeste, inspirada en el Apocalipsis y definida también por san Agustín: una ciudad amurallada, custodiada por ángeles, con torres de oro que simbolizaba el paraíso ${ }^{23}$. Este modelo geométricamente organizado y construido se vinculó rápidamente con la definición de las nuevas ciuda-

${ }^{23}$ Idea analizada en Rubial García, Antonio (2016): «El Apocalipsis en Nueva España. Los cambios de una tradición milenaria», en Conocimiento y cultura. Estudios modernos en la facultad de Filosofía y Letras. México: Universidad Nacional Autónoma de México, pp. 19-58. 


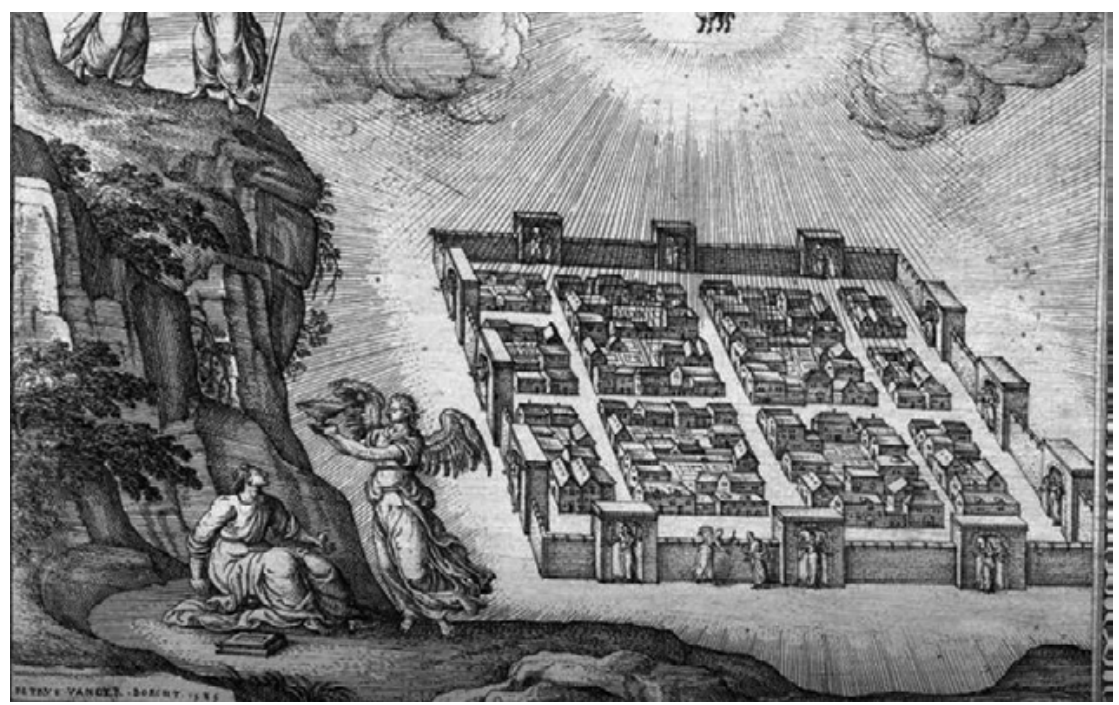

Pieter van der Borcht, detalle de Imagines et Figurae Bibliorum.

des, especialmente las americanas, fomentadas en los ámbitos de la implantación de las órdenes monásticas en los territorios conquistados. La definición de esta ciudad ideal no solo apareció en la planimetría urbana sino también en la plástica, cuyos modelos iconográficos se vieron complementados con la imagen urbana de Jerusalén, ya fuera identificada con Nueva España o con Sevilla, dentro de la libertad creativa de los pintores y de la influencia de órdenes como los agustinos, franciscanos o jesuitas. De tal forma que la ciudad celeste se volvió más terrenal, al ser perfectamente identificable dentro del orbe europeo, ya fuera entre las poblaciones del ámbito flamenco o identificada con Roma. Sin descartar la presencia de elementos orientales o, al menos, asociados a la mitología del Próximo Oriente. De esta manera, el modelo se transformó en una amalgama de construcciones de influencia diversa: órdenes clásicos, elementos orientales, torres medievales... formando una suma de estilos que se fueron repitiendo hasta conformar un tipo básico, fácil de identificar con la ciudad tres veces santa. Esta visión perfectamente ordenada de la ciudad de Jerusalén se parecía más, como dice Antonio Rubial, al diseño de un jardín francés geométricamente planificado que a la Jerusalén auténtica.

Estas referencias fueron utilizadas mayoritariamente en la pintura novohispana, como en la Exaltación franciscana a la Inmaculada Concepción (Museo de Arte de Querétaro, México), obra de 1637 de Basilio de Salazar (1613-1645)24. El autor

24 Véanse Rubial García, Antonio (1998): «Civitas Dei et novus orbis. La Jerusalén celeste en la pintura de Nueva España", en Anales del Instituto de Investigaciones Estéticas, n. ${ }^{\circ} 72$. México: 
mexicano tuvo la virtud de aunar esas dos visiones de la ciudad en esta interesante pintura, ya que partiendo de la idea de una Jerusalén cuadrangular y amurallada, coloca en su interior multitud de edificios tomados de referencias grabadas, en una combinación que, como hemos señalado, es frecuente en la pintura de los siglos XVI y xVII. La obra trataba de exaltar a la orden seráfica, de tal manera que sus doctores en teología son colocados casi por todas partes, situando a san Francisco en lo alto del monte Sión, a los pies de la Inmaculada, a semejanza de una Jerusalén franciscana, singular en cuanto a su representación de la ciudad celestial y claramente jerarquizada ${ }^{25}$. Salazar se inspiró en las mismas fuentes de las que bebían otros pintores coetáneos, dentro y fuera de México. Sin ir más lejos, en su Misa de san Gregorio (iglesia de San Felipe Neri, Guanajuato, México), fechada en 1645, parece usar la misma referencia grabada que en el homónimo lienzo atribuido, con reservas, a Gaspar de Quevedo y conservado en la iglesia de San Juan Bautista de La Orotava. Y no debemos olvidar que el propio Quintana hizo uso del mismo recurso en el cuadro que, con el mismo tema, conserva la catedral de La Laguna.

Los recursos grabados fueron un elemento de ida y vuelta, es decir, los tipos iconográficos se pueden encontrar de la misma manera en lienzos a miles de kilómetros de distancia, como en la Visión del juicio final de san Vicente Ferrer (Iglesia de san Felipe Neri, México), obra del pintor novohispano tal vez más destacado, Cristóbal de Villalpando, que pintó el mismo tipo de ciudad que Quintana, aunque algo menos desarrollada.

El pintor orotavense utilizó este recurso en varias ocasiones, pero de manera tan detallada y desarrollada solo lo hizo en dos ocasiones. En el lienzo que estudiamos y en el Señor de la Humildad y Paciencia con la Dolorosa y san Juan evangelista de la ermita de la Visitación, en Buenavista, hoy en la parroquia de esa localidad. Este paisaje arquitectónico que hace de telón de fondo es enormemente frecuente en los grabados que mencionábamos anteriormente. Tanto Sadeler, como los Wierix y van der Borcht lo utilizaron con mucha frecuencia, aunque solamente el último de ellos logrará complejas y bellísimas representaciones urbanas de la ciudad santa. Se puede decir que Quintana se copia a sí mismo en este asunto en los dos cuadros mencionados, pero no será tan fiel en otras obras en las que aparece ese mismo recurso, como en el San Francisco del retablo de Ravelo de la iglesia homónima del Puerto de la Cruz, en el San Juan Bautista de la iglesia de Santo Domingo de La Laguna, o en el San Simón y el San Judas de la ermita de San Jerónimo de Tacoronte. En todos ellos la arquitectura es testimonial, a veces solo una ruina; incluso algo difuminada y perdida en el paisaje. Únicamente en el Martirio de san Esteban y el Señor

Universidad Nacional Autónoma de México; y Moyssén, Xavier (1976): «Basilio de Salazar, un pintor del siglo xviı", en Anales del Instituto de Investigaciones Estéticas, 13 (46). México, pp. 49-57.

25 Véanse Rubial García, Antonio (2011): «Dos santos sin aureola. Las imágenes de Duns Scoto y la madre Águeda en la propaganda inmaculista franciscana», en La imagen sagrada y sacralizada. XXVIII Coloquio Internacional de Historia de Arte, vol. 2. México: Instituto de Investigaciones Estéticas, UNAM, pp. 563-580; y WobeSER, Gisela von (2015): Cielo, infierno y purgatorio durante el virreinato de la Nueva España. México: Universidad Nacional Autónoma de México, p. 105. 


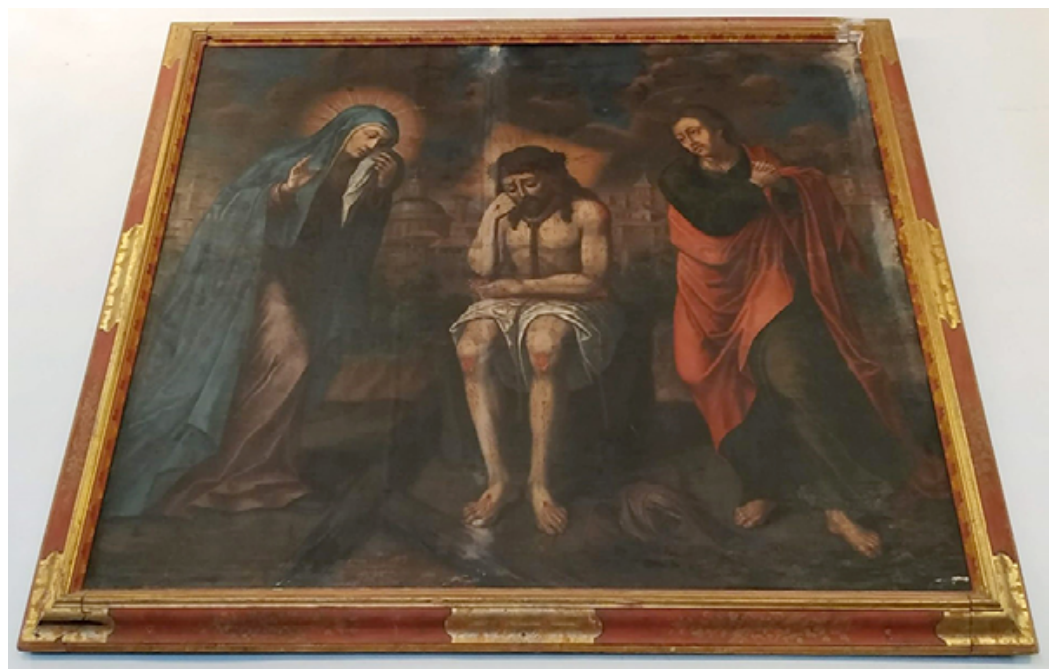

Atribuido a Cristóbal Hernández de Quintana, Señor de la Humildad y Paciencia con la Dolorosa y san Juan Evangelista. Parroquia de Nuestra Señora de los Remedios, Buenavista del Norte.

de la Humildad y Paciencia con la Dolorosa y san Juan evangelista, el pintor decide darle verdadero protagonismo. No obstante, en el segundo de los cuadros, si bien la arquitectura es muy parecida al cuadro orotavense, no está tan bien integrada en la escena, sirviendo solamente de recurso en el fondo del lienzo, aunque resulte bastante detallista. No hará lo mismo en La Piedad de la enfermería del convento clariso de San Cristóbal de La Laguna, que tiene una relación bastante directa con un grabado de la Virgen de Dolores de Antonius Wierix II, a partir de una obra de Maerten de Vos, en la que la figura de la Virgen es presentada en primer plano, sentada bajo la cruz ${ }^{26}$. En este caso la ciudad adquiere mayor presencia. De hecho, en el grabado original ocupa la parte central.

Es de sobra conocido que los hermanos Wierix están considerados unos de los mejores grabadores a caballo entre los siglos XVI y XVII. Desde su Amberes natal irradiaron su forma de grabar a toda la Europa cristiana y su influencia en los artistas del momento y posteriores puede ser considerada de las mayores en época barroca ${ }^{27}$.

26 También lo tiene de grabados de Hieronimus Wierix y Hendrick Goltzius. Véase MuÑIZ MuÑoz, Ángel (2015): «La ilustración del libro como generador de modelos. Pintores canarios del barroco y su relación con el grabado", en Anuario de Estudios Atlánticos, n. ${ }^{\circ}$ 61. Las Palmas de Gran Canaria: Cabildo Insular de Gran Canaria y Casa de Colón, p. 8.

27 Véase Pinilla Martín, María José (2010): «El Crucificado en la obra de los Wierix: una aproximación iconográfica», en Los crucificados, religiosidad, cofradias y arte: actas del Simposium. Valladolid: Universidad de Valladolid, pp. 579-594. 


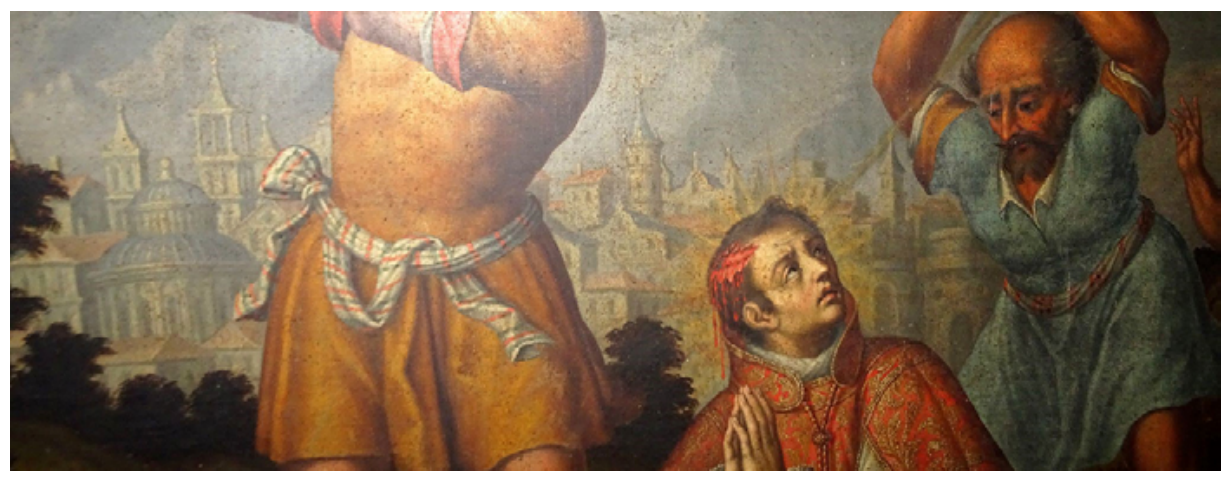

La ciudad de Jerusalén en El Martirio de San Esteban.

En muchas de las representaciones religiosas salidas de sus manos y que representaban escenas del Antiguo y Nuevo Testamento, aparecía la ciudad de Jerusalén. Esta presencia tenía su origen en los tratadistas del momento, que, como Montano, consideraron que era imprescindible que así fuera, de tal forma que los Wierix incluyeron este elemento de forma habitual en sus composiciones. Los modelos de ciudad utilizados por los hermanos Wierix se asemejan bastante a los usados por Borcht y de los que, sin ninguna duda, Quintana tomó las referencias. Este modelo, caracterizado por la acumulación de casas y torres, incluía la presencia del templo con su característica cúpula, pero mezclaba edificios de diversos estilos, dentro de lo que en aquella época podía calificarse de orientalizante.

Es indudable que Quintana contempló los grabados de los Wierix y de Pieter van der Borcht, probablemente a través de las numerosas publicaciones que los incluían. Pero no optó por la copia fiel a los modelos sino que utilizó las formas para componer su propio paisaje urbano. Casi como un collage, el artista tomó edificios de uno y otro grabado y formó su propia ciudad, pero de clara inspiración antuerpiense. Los ejemplos en los que esta Jerusalén aparece en los grabados de estos artistas son realmente numerosos, así que la probabilidad de que Quintana tuviese acceso a ellos es realmente alta. La ciudad pintada por Quintana está muy cerca de los diseños de Hieronymus Wierix y Borcht para escenas como El señor del huerto o la Entrada de Jesús en Jerusalén, grabados realizados hacia 1583 e incluidos en diversas publicaciones. Pudo contemplar otro lienzo que se encuentra actualmente en la misma sacristía que el Martirio de san Esteban, aunque su procedencia es incierta. Nos referimos al Entierro de Cristo, una obra de finales del siglo XVI o principios del XVII, probablemente de origen sevillano, pero de clara influencia flamenca. La escena, tomada de un grabado de Jan Collaert que acompañaba a la Vita, Passio et resurrectio Iesu Christi, publicada en Amberes antes de 1618, parte de una obra de Maerten de Vos, en la que, en la lejanía, vemos la ciudad de Jerusalén como un pequeño grupo de edificios cilíndricos entre los que destaca el templo, pero a la 
manera europea ${ }^{28}$. Aunque lo cierto es que Quintana no tenía sino que consultar la multitud de grabados incluidos en la Biblia van Borcht para obtener su modelo.

Esta urbe ciertamente idealizada incluía un componente fundamental para su correcta representación: las murallas. Las de Jerusalén incluían ocho puertas, una de las cuales fue conocida en el ámbito cristiano como puerta de san Esteban por haber tenido lugar la lapidación del santo a las afueras de la misma, aunque su nombre real es puerta de los leones, por los bajorrelieves que la adornan. Su significación era enorme pues desembocaba en el monte de los Olivos. La podemos ver representada en muchos grabados, como en uno de Cornelis Cort a partir de Marcello Venusti que conserva la Biblioteca Nacional de España, fechado en 1577 y que representa el martirio del santo, cuyas formas recuerdan la composición típica de la escena que inspiró también a Quintana.

Pero él no fue el único pintor que en Canarias incluyó esa visión de la ciudad en sus composiciones. A este respecto resulta interesante la imagen de Jerusalén en el fondo del lienzo que, representando al Crucificado, ocupa el lugar central del segundo cuerpo del retablo mayor de la parroquia de san Antonio Abad de Arona. Esta estructura procede del convento franciscano de Adeje y fue trasladada a Arona hacia 1842 , tras las reformas emprendidas en esta parroquia y gracias a la desamortización $^{29}$. Se trata de un retablo datado en el último cuarto del siglo XVIII, con decoración a base de pilastras abalaustradas y profusa decoración chinesca y vegetal, en cuyo segundo cuerpo se halla la citada pintura, acompañada, a derecha e izquierda, por san Francisco y santo Domingo, en clara alusión a la procedencia monástica del mismo. La composición, siendo muy elemental, no deja de ser curiosa puesto que juega con todos los elementos clásicos de la escena: el sol, la luna, las nubes que abren el cielo, el paisaje montańoso, los árboles y el conjunto de casas a modo de bloques cúbicos salpicado de altas torres. Las tres pinturas parecen ser obra de un mismo artista, deudor del arcaismo que aún presentaba cierta plástica del setecientos, a la estela de los modelos de Quevedo y Quintana.

La ciudad también aparece como trasfondo en una de las tablas del retablo de Mazuelos, concretamente en la que representa al Calvario y que se encuentra en la ermita de San Vicente de Los Realejos. La composición de Hendrick van Balen recuerda inevitablemente a otras tantas representaciones de este momento bíblico. No obstante, en este caso se enmarca en un delicado paisaje, en el que sobresalen las líneas del templo, intencionadamente resaltado en blanco. También en el lienzo que representa a Cristo Crucificado, la Dolorosa y san Sebastián (iglesia del Hospi-

${ }^{28}$ Véase Rodríguez Bravo, Jesús (2017): «Pintura», en El Tesoro. Catálogo del Museo Sacro de la Parroquia de Nuestra Señora de La Concepción de La Orotava. Santa Cruz de Tenerife: Gobierno de Canarias y Parroquia Matriz de Nuestra Señora de La Concepción de La Orotava, p. 46.

29 Hernández GonzÁlez, Manuel Jesús (2015): «Contribución a la retablística pintada del siglo XviII. Algunos ejemplos en el sur de Tenerife», en III Jornadas de historia del sur de Tenerife. Arona: concejalía de patrimonio histórico del Ayuntamiento de Arona, p. 413. Señala que el autor de este retablo pudo ser el mismo que realizó el homónimo de la parroquia de Santa Úrsula de Adeje. No en vano, el ejemplar de Arona procede del convento franciscano de esa misma localidad. 
tal de Nuestra Señora de los Dolores, La Laguna), encargado por Pedro López de Villera y datado hacia 1521, se nos muestra una Jerusalén amurallada con edificios en su interior, aunque en este caso, tal vez Quintana no lo contemplara como tal, ya que fue repintado en el siglo XVIII.

Juan de Miranda también usa una imagen bucólica de la ciudad santa en su Entrada triunfal de Jesús en Jerusalén (c. 1780-1790, Museo Municipal de Bellas Artes de Santa Cruz de Tenerife). Las referencias formales de esta obra nos remiten a las composiciones de Johann Sadeler, Maarten van Heemskreck, los hermanos Wierix o Hans Collaert, que repetían los elementos tradicionales de esta escena. Sin embargo, como suele suceder con Miranda, su maestría le lleva a crear su propia idea de ciudad, con una extraordinaria sutileza en los colores elegidos y en las formas de los edificios, acercándose más a las composiciones de Jan Luyken. Similar forma de componer demuestra en su versión de la Lapidación de san Esteban (colección particular, procedente de los marqueses de La Florida). A diferencia de Quintana, la obra de Miranda se centra en la figura mística del santo, dejando al margen la crueldad del martirio en $s^{i 30}$. Este extraordinario lienzo, elaborado a modo de tondo, recuerda en la figura del santo a grabados de Alexander Voet, datados en la segunda mitad del siglo Xvir; e incluso entronca con el Martirio de san Esteban del veneciano Antonio Zanchi (Museo del Prado, s. XVII) o con un grabado a partir de la misma obra de Rosso Fiorentino, evidenciando cierto gusto italiano en la composición del canario.

No sabemos hasta qué punto Cristóbal Hernández de Quintana, algo irregular en el conjunto de su obra, era consciente del valor de las fuentes que utilizaba. Más bien creemos que fue especialmente hábil a la hora de combinarlas y obtener buenos resultados, aunque hay que decir que no siempre lo logró de manera satisfactoria. No obstante, habría que concederle el beneplácito de la duda, ya que sí demostró, a lo largo de su extensa carrera artística, la capacidad de asimilar y recrear las imágenes que obtenía de sus fuentes. Y, sin duda, lo que el mayordomo Domingo de Valcárcel vio en aquel cuadro fue lo que luego la historia del Arte en Canarias se ha encargado de comprobar: que la fama del pintor y la valía de sus obras le hicieron ser reconocido, incluso después de haber desaparecido.

ReCiBIDO: 22-3-2021; ACEPTADO: 15-4-2021

${ }^{30}$ Idea expresada en Lorenzo Lima, Juan Alejandro (2011): Juan de Miranda. Reverso de un autorretrato. Las Palmas de Gran Canaria: Gaviño de Franchi Editores, p. 159 y siguientes. 
